Article

\title{
Barium Oxalates Combined with Oxo-Anions and Organic Cations: Syntheses and Structures of $\mathrm{Ba}_{2}\left(\mathrm{C}_{2} \mathrm{O}_{4}\right)\left(\mathrm{H}_{2} \mathrm{PO}_{3}\right)_{2}$ and $\mathrm{C}_{2} \mathrm{H}_{10} \mathrm{~N}_{2} \cdot \mathrm{Ba}\left(\mathrm{H}_{2} \mathrm{O}\right)_{2}\left(\mathrm{HC}_{2} \mathrm{O}_{4}\right)_{4}$
}

\author{
Samuel J. Iveson, Chloe B. Johnston and William T.A. Harrison * \\ Department of Chemistry, University of Aberdeen, Meston Walk, Aberdeen AB24 3UE, Scotland, UK \\ * Author to whom correspondence should be addressed; E-Mail: w.harrison@abdn.ac.uk; \\ Tel.: +44-1224-272897; Fax: +44-1224-272921.
}

Received: 25 May 2011; in revised form: 1 June 2011 / Accepted: 7 June 2011 /

Published: 8 June 2011

\begin{abstract}
The syntheses and single-crystal structures of $\mathrm{Ba}_{2}\left(\mathrm{C}_{2} \mathrm{O}_{4}\right)\left(\mathrm{H}_{2} \mathrm{PO}_{3}\right)_{2}$ (1) and $\mathrm{C}_{2} \mathrm{H}_{10} \mathrm{~N}_{2} \cdot \mathrm{Ba}\left(\mathrm{H}_{2} \mathrm{O}\right)_{2}\left(\mathrm{HC}_{2} \mathrm{O}_{4}\right)_{4}(2)$ are described. Compound $\mathbf{1}$ is a three-dimensional mixedanion framework containing $\mathrm{BaO}_{9}$ coordination polyhedra, which approximate to monocapped square anti-prisms: the connectivity of the $\mathrm{BaO}_{9}$ units via edges and triangular faces leads to a sheet structure. The oxalate ion in $\mathbf{1}$ is substantially twisted about its $\mathrm{C}-\mathrm{C}$ bond [dihedral angle between the $\mathrm{CO}_{2}$ groups $=33.8(3)^{\circ}$ ]. Compound 2 is a molecular salt containing ethylenediammonium dications and $\left[\mathrm{Ba}\left(\mathrm{HC}_{2} \mathrm{O}_{4}\right)_{4}\left(\mathrm{H}_{2} \mathrm{O}\right)_{2}\right]^{2-}$ dianions, which are linked by $\mathrm{O}-\mathrm{H} \cdots \mathrm{O}$ and $\mathrm{N}-\mathrm{H} \cdots \mathrm{O}$ hydrogen bonds. The $\mathrm{BaO}_{10}$ coordination polyhedron can be described as a distorted pentagonal anti-prism. Crystal data: $1 \quad\left(\mathrm{C}_{2} \mathrm{H}_{4} \mathrm{Ba}_{2} \mathrm{O}_{10} \mathrm{P}_{2}\right)$, $M_{\mathrm{r}}=524.68$, monoclinic, $C 2 / c$ (No. 15), $Z=4, a=12.3829$ (3) $\AA, b=7.9124$ (2) $\AA$, $c=11.0858$ (3) $\AA, \beta=114.788(2)^{\circ}, V=986.10(4) \AA^{3}, R(F)=0.016, w R\left(F^{2}\right)=0.040 .2$ $\left(\mathrm{C}_{10} \mathrm{H}_{18} \mathrm{BaN}_{2} \mathrm{O}_{10}\right), M_{\mathrm{r}}=591.60$, monoclinic, $C 2 / m$ (No. 12), $Z=2, a=12.7393$ (7) $\AA$, $b=13.0111$ (7) $\AA, c=5.6050$ (3) $\AA, \beta=104.208(4)^{\circ}, V=900.62$ (8) $\AA^{3}, R(F)=0.027$, $w R\left(F^{2}\right)=0.054$.
\end{abstract}

Keywords: barium; oxalate; crystal structure; polyhedra; hydrogen bonding 


\section{Introduction}

Hydrated barium oxalates including $\mathrm{Ba}\left(\mathrm{C}_{2} \mathrm{O}_{4}\right) \cdot \frac{1}{2} \mathrm{H}_{2} \mathrm{O}$ [1], $\mathrm{Ba}\left(\mathrm{C}_{2} \mathrm{O}_{4}\right) \cdot \mathrm{H}_{2} \mathrm{O}$ [2], $\mathrm{Ba}\left(\mathrm{C}_{2} \mathrm{O}_{4}\right) \cdot 2 \mathrm{H}_{2} \mathrm{O}$ [3] and $\mathrm{Ba}\left(\mathrm{C}_{2} \mathrm{O}_{4}\right) \cdot 3 \frac{1}{2} \mathrm{H}_{2} \mathrm{O}$ [4], which feature various bridging and coordination modes of the oxalate ions, are a well studied family of inorganic compounds [5]. Of particular interest is the topotactic dehydration of $\mathrm{Ba}\left(\mathrm{C}_{2} \mathrm{O}_{4}\right)\left(\mathrm{H}_{2} \mathrm{C}_{2} \mathrm{O}_{4}\right) \cdot 2 \mathrm{H}_{2} \mathrm{O}$ to yield the polymorphs $\alpha-\mathrm{Ba}\left(\mathrm{C}_{2} \mathrm{O}_{4}\right)\left(\mathrm{H}_{2} \mathrm{C}_{2} \mathrm{O}_{4}\right)$ and $\beta-\mathrm{Ba}\left(\mathrm{C}_{2} \mathrm{O}_{4}\right)\left(\mathrm{H}_{2} \mathrm{C}_{2} \mathrm{O}_{4}\right)$, which serves as a model system for this type of reaction [6,7]. Barium oxalate is used to prepare barium titanyl oxalate, which is an important molecular precursor to barium titanate, $\mathrm{BaTiO}_{3}$ [8]. A more exotic application for barium oxalates is to impart a green color to pyrotechnics [9]. A quite different crystallochemical aspect of the oxalate ion is its structural role in forming organically-templated oxalate/oxo-anion open frameworks such as $\mathrm{C}_{4} \mathrm{H}_{12} \mathrm{~N}_{2} \cdot\left[\mathrm{Fe}_{4}\left(\mathrm{HPO}_{3}\right)_{2}\left(\mathrm{C}_{2} \mathrm{O}_{4}\right)_{3}\right]$ [10] or $\mathrm{C}_{6} \mathrm{H}_{14} \mathrm{~N}_{2} \cdot\left[\mathrm{In}_{2}\left(\mathrm{HPO}_{3}\right)_{3}\left(\mathrm{C}_{2} \mathrm{O}_{4}\right)\right]$ [11].

Although these types of metal-mixed-anion frameworks have been reported for a number of transition and main-group metals and rare earths [12], similar studies of barium oxalates either in combination with oxo-anions such as hydrogen phosphite or with organic cations are in their infancy. In this paper, we describe the syntheses and crystal structures of two new representative compounds in this family, namely $\mathrm{Ba}_{2}\left(\mathrm{C}_{2} \mathrm{O}_{4}\right)\left(\mathrm{H}_{2} \mathrm{PO}_{3}\right)_{2}$ (1) and $\mathrm{C}_{2} \mathrm{H}_{10} \mathrm{~N}_{2} \cdot \mathrm{Ba}\left(\mathrm{H}_{2} \mathrm{O}\right)_{2}\left(\mathrm{HC}_{2} \mathrm{O}_{4}\right)_{4}$ (2).

\section{Results and Discussion}

\subsection{Crystal structure of $\mathrm{Ba}_{2}\left(\mathrm{C}_{2} \mathrm{O}_{4}\right)\left(\mathrm{H}_{2} \mathrm{PO}_{3}\right)_{2}(\mathbf{1})$}

The asymmetric unit of 1 (Figure 1) contains a barium cation, an $\left(\mathrm{H}_{2} \mathrm{PO}_{3}\right)^{-}$dihydrogen phosphite (dhp) ion and half an oxalate ion: the latter is completed by crystallographic 2-fold symmetry.

Figure 1. A fragment of 1 showing 50\% displacement ellipsoids for the non-hydrogen atoms. The $\mathrm{O}-\mathrm{H} \cdots \mathrm{O}$ hydrogen bond is shown as a double-dashed line. See Table 1 for symmetry codes.

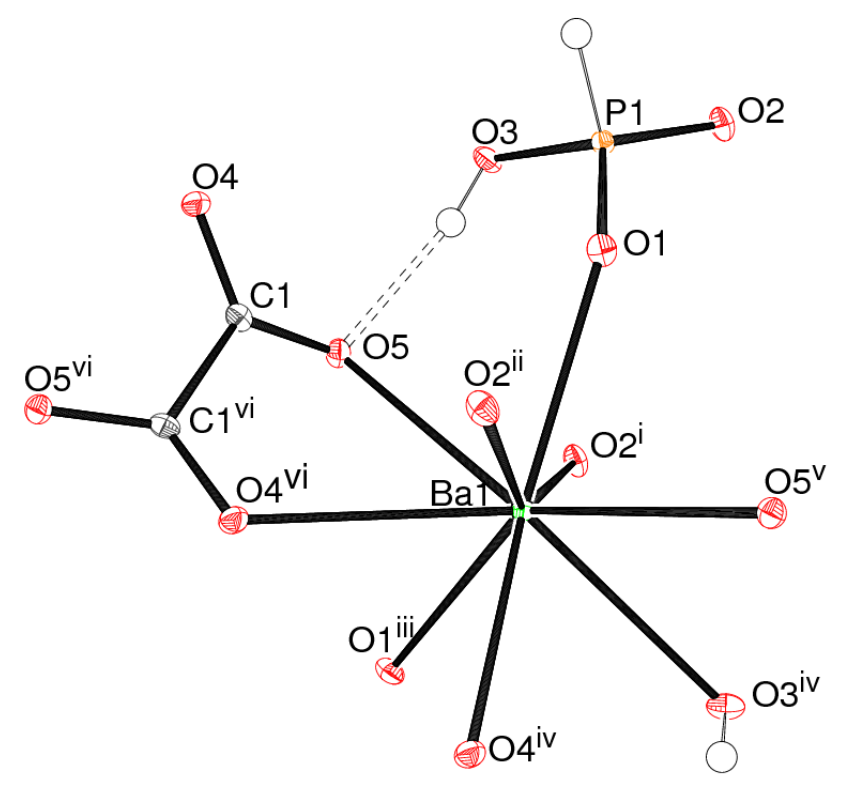


The barium ion in $\mathbf{1}$ is coordinated by nine oxygen atoms, with a mean $\mathrm{Ba}-\mathrm{O}$ separation of $2.824 \AA$ (Table 1): the next-nearest $\mathrm{O}$ atom is over $3.9 \AA$ from the metal ion. The bond valence sum (BVS) value for Ba1, as calculated by the Brown-Altermatt formalism [13], is 2.16, compared to an expected value of 2.00. Four of the $\mathrm{O}$ atoms are parts of oxalate ions and five are from adjacent dhp ions. The polyhedral geometry of the metal ion (Figure 2) is quite well described as a monocapped square antiprism [14], with $\mathrm{O} 1 / \mathrm{O} 2^{\mathrm{i}} / \mathrm{O}^{\mathrm{iv}} / \mathrm{O}^{\mathrm{v}}$ (see Table 1 for symmetry codes) forming one square face (r.m.s. deviation $=0.045 \AA$ ) and $\mathrm{O} 1^{\mathrm{iii}} / \mathrm{O} 2^{\mathrm{ii}} / \mathrm{O} 4^{\mathrm{iv}} / \mathrm{O} 5$ (r.m.s. deviation $=0.097 \AA$ ) the other: the dihedral angle between the two mean planes is $10.78(6)^{\circ}$. Atom $\mathrm{O} 4^{\mathrm{vi}}$ projects through the second of these faces to provide the cap. The Ba atom is displaced by 1.4843 (9) $\AA$ from the first plane and by -1.1191 (8) $\AA$ from the second.

Figure 2. The monocapped square anti-prismatic barium-ion coordination polyhedron in $\mathbf{1}$.

See Table 1 for symmetry codes.

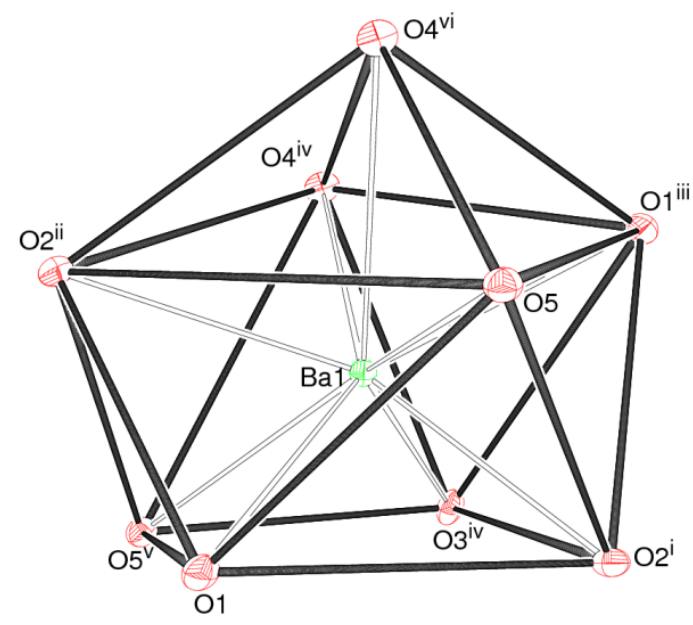

Table 1. Selected geometrical data $\left(\AA,^{\circ}\right)$ for $\mathbf{1}$.

\begin{tabular}{|l|l|l|l|}
\hline $\mathrm{Ba} 1-\mathrm{O} 2^{\mathrm{i}}$ & $2.6927(18)$ & $\mathrm{Ba} 1-\mathrm{O} 1$ & $2.7322(18)$ \\
\hline $\mathrm{Ba} 1-\mathrm{O} 2^{\mathrm{ii}}$ & $2.7519(18)$ & $\mathrm{Ba}^{\mathrm{ii}}-\mathrm{O} 1^{\mathrm{ii}}$ & $2.7894(18)$ \\
\hline $\mathrm{Ba} 1-\mathrm{O} 4^{\mathrm{iv}}$ & $2.7929(19)$ & $\mathrm{Ba} 1-\mathrm{O} 5$ & $2.8818(17)$ \\
\hline${\mathrm{Ba} 1-\mathrm{O} 5^{\mathrm{v}}}_{\mathrm{Ba} 1-\mathrm{O} 3^{\mathrm{iv}}}^{2.9101(18)}$ & $\mathrm{Ba} 1-\mathrm{O} 4^{\mathrm{vi}}$ & $2.9202(18)$ \\
\hline $\mathrm{P} 1-\mathrm{O} 1$ & $2.9453(19)$ & $\mathrm{P} 1-\mathrm{O} 2$ & $1.5013(17)$ \\
\hline $\mathrm{P} 1-\mathrm{H} 1$ & $1.5015(19)$ & $\mathrm{P} 1-\mathrm{O} 3$ & $1.595(2)$ \\
\hline $\mathrm{C} 1-\mathrm{O} 5$ & $1.25(3)$ & $\mathrm{C} 1-\mathrm{O} 4$ & $1.244(3)$ \\
\hline
\end{tabular}

\begin{tabular}{|l|l|l|l|}
\hline $\mathrm{O} 2-\mathrm{P} 1-\mathrm{O} 1$ & $117.92(10)$ & $\mathrm{O} 2-\mathrm{P} 1-\mathrm{O} 3$ & $108.92(11)$ \\
\hline $\mathrm{O} 1-\mathrm{P} 1-\mathrm{O} 3$ & $110.65(11)$ & $\mathrm{O} 4-\mathrm{C} 1-\mathrm{O} 5$ & $126.5(2)$ \\
\hline $\mathrm{O} 4-\mathrm{C} 1-\mathrm{C}^{\mathrm{vi}}$ & $117.0(2)$ & $\mathrm{O} 5-\mathrm{C} 1-\mathrm{C} 1^{\mathrm{vi}}$ & $116.3(3)$ \\
\hline
\end{tabular}

\begin{tabular}{|l|l|l|l|l|}
\hline $\mathrm{O} 3-\mathrm{H} 2 \cdots \mathrm{O} 5$ & $0.79(4)$ & $1.87(4)$ & $2.647(3)$ & $168(3)$ \\
\hline
\end{tabular}

Symmetry codes: (i) $1 / 2-x, 1 / 2-y, 1-z$; (ii) $x, 1-y, 1 / 2+z$; (iii) $1 / 2-x, y-1 / 2,1 \frac{1}{2}-z$; (iv) $1 / 2+x, 1 / 2-y, 1 / 2+z$; (v) $1 / 2-x, 1 / 2+y, 1 \frac{1}{2}-z ;$ (vi) $-x, y, 1 \frac{1}{2}-z$. 
The dhp anion in $\mathbf{1}$ adopts its normal tetrahedral geometry [15]: the phosphorus(III) atom is displaced by 0.4268 (13) $\AA$ from its three attached $\mathrm{O}$ atoms and the fourth vertex is occupied by the $\mathrm{P}-$ $\mathrm{H}$ grouping. The $\mathrm{P} 1-\mathrm{O} 3$ bond length is substantially longer than the other two $\mathrm{P}-\mathrm{O}$ bonds, due to its protonation: the $\mathrm{P}-\mathrm{OH}$ group forms an $\mathrm{O}-\mathrm{H} \cdots \mathrm{O}$ hydrogen bond to an acceptor oxalate $\mathrm{O}$ atom (Figure 1, Table 1). As usual, the $\mathrm{P}-\mathrm{H}$ vertex does not participate in hydrogen bonding interactions [16].

Figure 3. Polyhedral view of the (100) sheets of $\mathrm{BaO}_{9}$ polyhedra in $\mathbf{1}$.

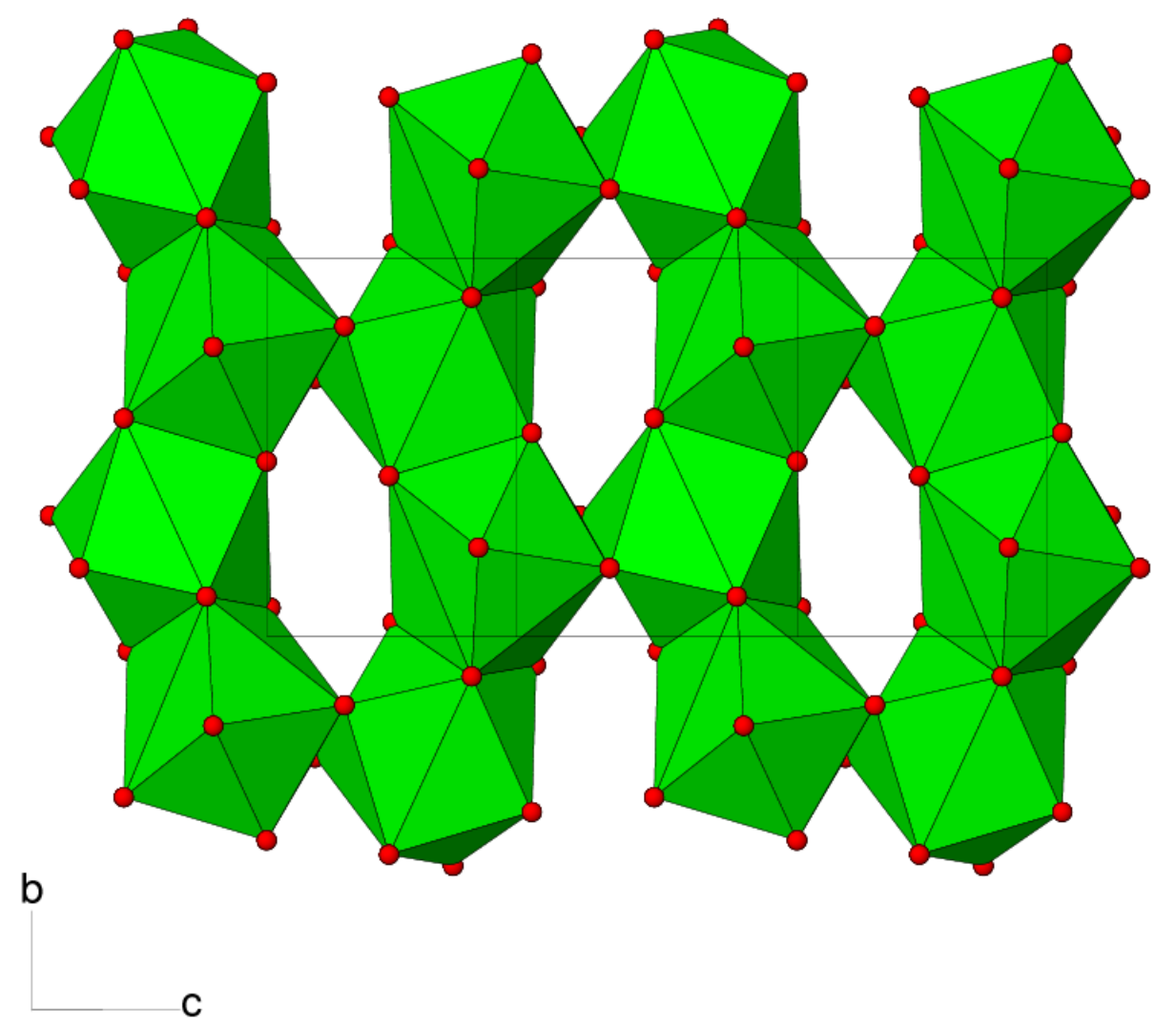

The $\mathrm{C}-\mathrm{O}$ bonds in the oxalate dianion in $\mathbf{1}$ show slightly different lengths, possibly due to packing effects or because $\mathrm{O} 5$ is the hydrogen-bond acceptor. The dihedral angle between the two $-\mathrm{CO}_{2}$ groups is $33.8(3)^{\circ}$, indicating a substantial degree of twisting about the central $\mathrm{C}-\mathrm{C}$ bond. Oxalate ions in crystal structures are more commonly close to planar [17], although a similar degree of twist has long been known in $\left(\mathrm{NH}_{4}\right)_{2}\left(\mathrm{C}_{2} \mathrm{O}_{4}\right) \cdot \mathrm{H}_{2} \mathrm{O}$ [18]. Interestingly, this twisting renders the isolated oxalate ion an enantiomorphous (chiral) object [19], with local $C_{2}$ symmetry. This 2-fold symmetry is crystallographically imposed for the oxalate ion in $\mathbf{1}$, but of course, the presence of crystallographic inversion symmetry in space group $C 2 / c$ leads to a racemic overall structure. The $\mathrm{C}-\mathrm{C}$ bond length is $\mathbf{1}$ is notably long at 1.550 (5) $\AA$, a feature also seen in the ammonium compound [18].

The connectivity of the polyhedral building units in $\mathbf{1}$ leads to a three-dimensional framework constructed from $\mathrm{BaO}_{9}, \mathrm{H}_{2} \mathrm{PO}_{3}$ and $\mathrm{C}_{2} \mathrm{O}_{4}$ building blocks. Considered by themselves, the $\mathrm{BaO}_{9}$ polyhedra share both edges (via O4/O4) in the $c$ direction and faces (via O1/O2/O5) in the $b$ direction to generate (100) sheets (Figure 3). The oxalate ions and dhp ions complete the packing to generate a dense three-dimensional network, without any indication of channels or pores. 


\subsection{Structure of $\mathrm{C}_{2} \mathrm{H}_{10} \mathrm{~N}_{2} \cdot \mathrm{Ba}\left(\mathrm{H}_{2} \mathrm{O}\right)_{2}\left(\mathrm{HC}_{2} \mathrm{O}_{4}\right)_{4}$ (2)}

Compound 2 (Figure 4) is a molecular salt built up from a barium ion lying on a special position at the origin with $2 / m$ site symmetry, an $\left(\mathrm{HC}_{2} \mathrm{O}_{4}\right)^{-}$hydrogen oxalate monoanion, a water molecule $(\mathrm{O}$ atom site symmetry $m$ ) and half a $\left[\mathrm{C}_{2} \mathrm{H}_{10} \mathrm{~N}_{2}\right]^{2+}$ ethylenediammonium cation, with both the $\mathrm{N}$ and the $\mathrm{C}$ atom lying on a crystallographic mirror plane. The complete organic cation is completed by inversion symmetry.

Figure 4. The molecular structure of 2 showing 50\% displacement ellipsoids. Symmetry codes: (i) $-x,-y,-z$; (ii) $-x, y,-z$; (iii) $x,-y, z$; (iv) $1-x,-y, 1-z$.

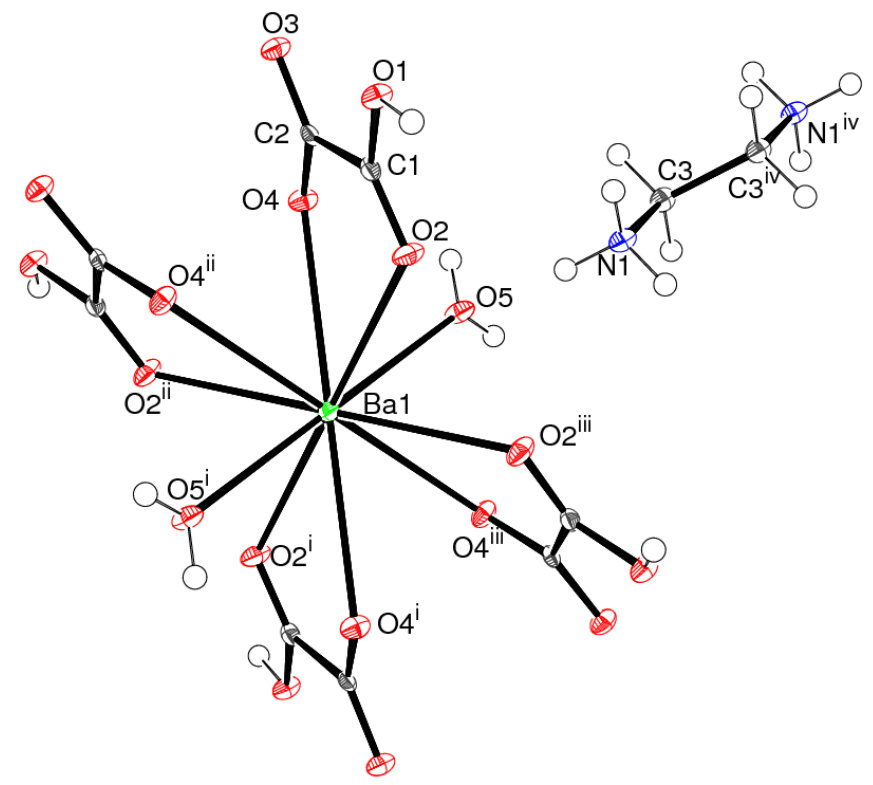

Figure 5. The pentagonal antiprismatic $\mathrm{BaO}_{10}$ coordination polyhedron in 2 showing $50 \%$ displacement ellipsoids. The lilac and fuchsia lines delineate the top and bottom pentagonal faces, respectively. Symmetry codes as in Figure 4.

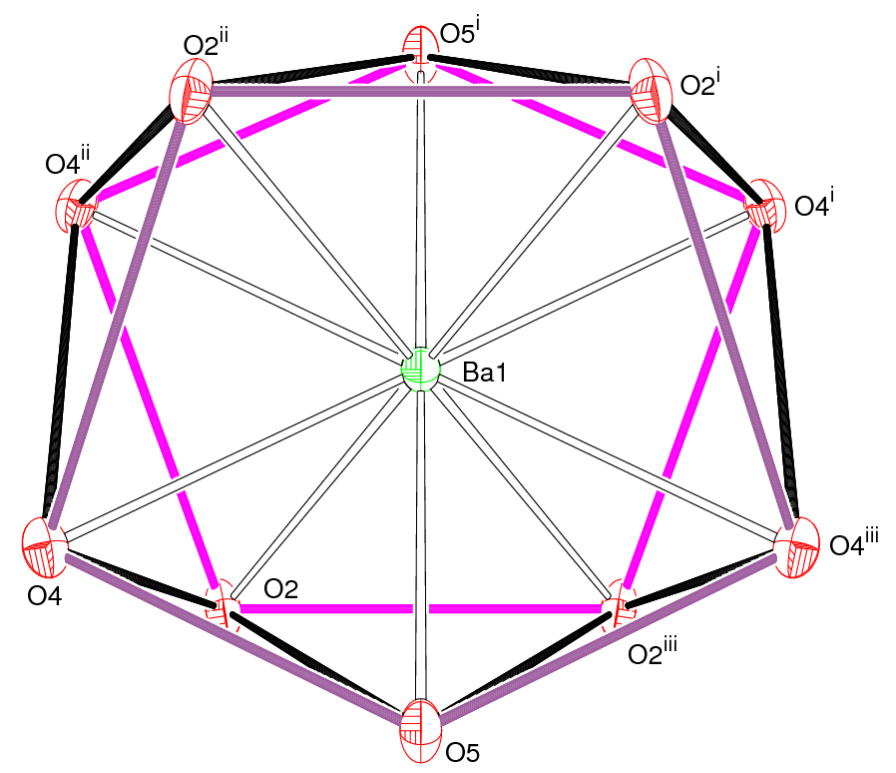


Table 2. Selected geometrical data $\left(\AA,{ }^{\circ}\right)$ for 2 .

\begin{tabular}{|l|l|l|l|}
\hline $\mathrm{Ba} 1-\mathrm{O} 5$ & $2.781(2)$ & $\mathrm{Ba} 1-\mathrm{O} 2$ & $2.8178(17)$ \\
\hline $\mathrm{Ba} 1-\mathrm{O} 4$ & $2.9586(17)$ & $\mathrm{C} 1-\mathrm{O} 2$ & $1.215(3)$ \\
\hline $\mathrm{C} 1-\mathrm{O} 1$ & $1.301(3)$ & $\mathrm{C} 1-\mathrm{C} 2$ & $1.548(2)$ \\
\hline $\mathrm{C} 2-\mathrm{O} 3$ & $1.240(3)$ & $\mathrm{C} 2-\mathrm{O} 4$ & $1.265(3)$ \\
\hline $\mathrm{C} 3-\mathrm{N} 1$ & $1.493(5)$ & $\mathrm{C} 3-\mathrm{C} 3^{\text {iv }}$ & $1.501(7)$ \\
\hline
\end{tabular}

\begin{tabular}{|l|l|l|l|}
\hline $\mathrm{O} 2-\mathrm{C} 1-\mathrm{O} 1$ & $125.6(2$ & $\mathrm{O} 2-\mathrm{C} 1-\mathrm{C} 2$ & $121.4(2)$ \\
\hline $\mathrm{O} 1-\mathrm{C} 1-\mathrm{C} 2$ & $113.0(2)$ & $\mathrm{O} 3-\mathrm{C} 2-\mathrm{O} 4$ & $127.2(2)$ \\
\hline $\mathrm{O} 3-\mathrm{C} 2-\mathrm{C} 1$ & $118.3(2)$ & $\mathrm{O} 4-\mathrm{C} 2-\mathrm{C} 1$ & $114.4(2)$ \\
\hline $\mathrm{N} 1-\mathrm{C} 3-\mathrm{C}{ }^{\text {iv }}$ & $109.5(4)$ & & \\
\hline
\end{tabular}

\begin{tabular}{|l|l|l|l|l|}
\hline $\mathrm{O} 1-\mathrm{H} 1 \cdots \mathrm{O} 4^{\mathrm{v}}$ & 1.00 & 1.50 & $2.504(2)$ & 176 \\
\hline $\mathrm{O} 5-\mathrm{H} 5 \cdots \mathrm{O} 3^{\mathrm{vii}}$ & 0.85 & 2.00 & $2.841(2)$ & 172 \\
\hline $\mathrm{N} 1-\mathrm{H} 2 \cdots \mathrm{O} 5$ & 0.89 & 1.99 & $2.824(4)$ & 156 \\
\hline $\mathrm{N} 1-\mathrm{H} 3 \cdots \mathrm{O} 3^{\mathrm{vi}}$ & 0.89 & 1.98 & $2.839(3)$ & 163 \\
\hline $\mathrm{N} 1-\mathrm{H} 3 \cdots \mathrm{O} 1^{\mathrm{vi}}$ & 0.89 & 2.40 & $2.9765(17)$ & 123 \\
\hline
\end{tabular}

Symmetry codes: (iv) $1-x,-y, 1-z$; (v) $x, y, 1+z$; (vi) $1 / 2-x, 1 / 2-y, 1-z$; (vii) $1 / 2-z, 1 / 2-y,-z$.

Figure 6. The unit-cell packing for 2 with the $\mathrm{BaO}_{10}$ groups shown as green polyhedra and the $\mathrm{H} \cdots \mathrm{O}$ segments of the hydrogen bonds highlighted in cyan.

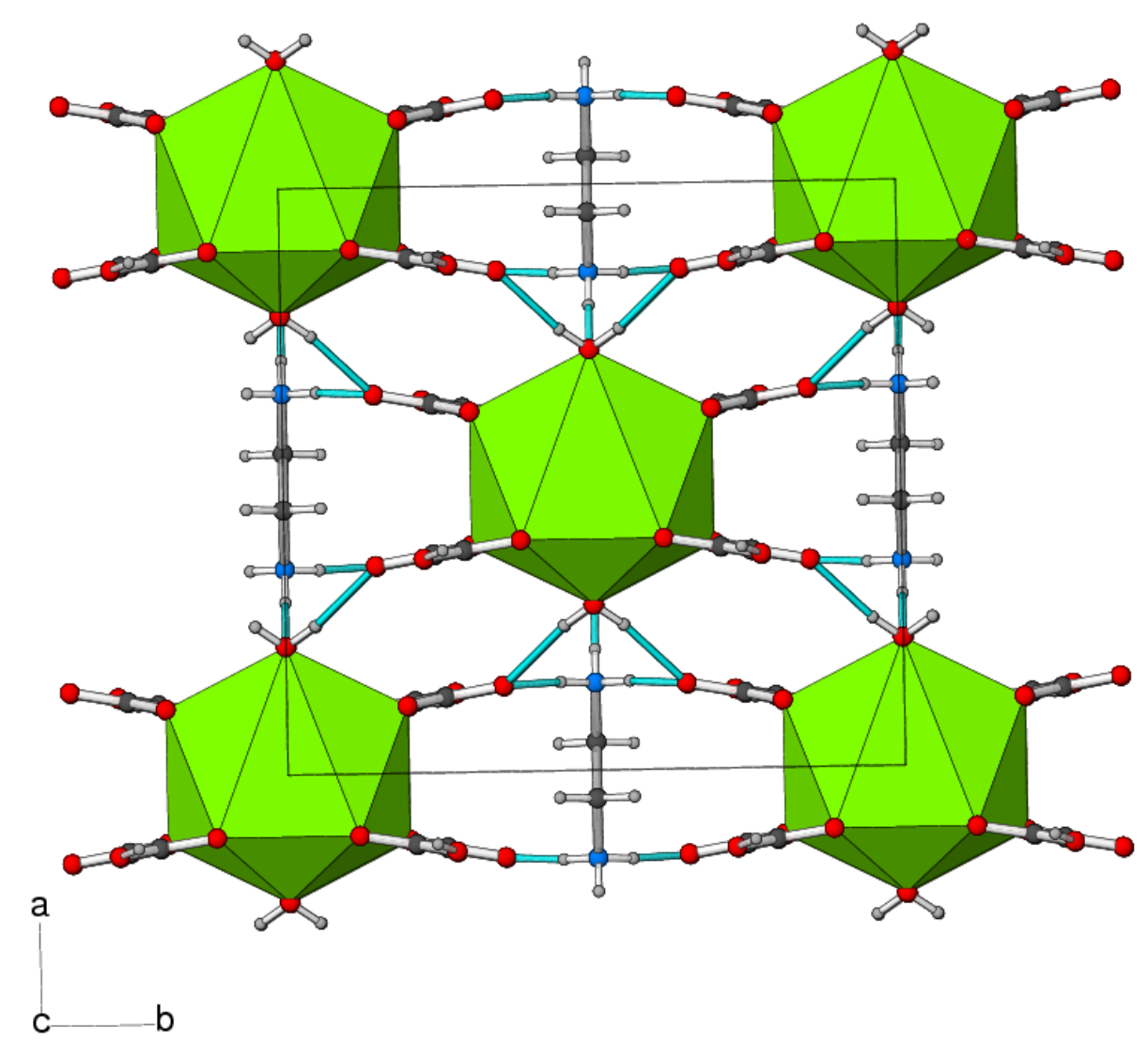

The barium ion in $\mathbf{2}$ is 10 -coordinated by four bidentate hydrogen oxalate anions and two water molecules (Table 2) as a $\left[\mathrm{Ba}\left(\mathrm{H}_{2} \mathrm{O}\right)_{2}\left(\mathrm{HC}_{2} \mathrm{O}_{4}\right)_{4}\right]^{2-}$ dianion: the mean $\mathrm{Ba}-\mathrm{O}$ separation is $2.867 \AA$ and 
$\operatorname{BVS}(\mathrm{Ba} 1)=2.12$ The polyhedral geometry about the metal ion can be described as a pentagonal antiprism [20] (Figure 5), although the pentagonal faces are significantly puckered into envelopes with O5 at the flap position pointing away from the barium ion. The dihedral angle between the mean planes is constrained by symmetry to be zero and $\mathrm{Ba}$ is displaced from each plane by 1.271 (2) $\AA$.

The hydrogen oxalate ion is $\mathbf{2}$ is almost planar, as indicated by the $\mathrm{C} 1 / \mathrm{O} 1 / \mathrm{O} 2-\mathrm{C} 2 / \mathrm{O} 3 / \mathrm{O} 4$ dihedral angle of $1.0(3)^{\circ}$. Unlike the case in 1, the oxalate $\mathrm{C}-\mathrm{C}$ bond length in 2 of 1.501 (7) $\AA$ is quite typical for a carbon-carbon single bond. The $\left[\mathrm{C}_{2} \mathrm{H}_{10} \mathrm{~N}_{2}\right]^{2+}$ ethylenediammonium ion in $\mathbf{2}$ shows no unusual features; the $\mathrm{N}-\mathrm{C}-\mathrm{C}-\mathrm{N}$ torsion angle is constrained by symmetry to be $-180^{\circ}$.

In the crystal of $\mathbf{2}$, the components are linked by $\mathrm{N}-\mathrm{H} \cdots \mathrm{O}$ and $\mathrm{O}-\mathrm{H} \cdots \mathrm{O}$ hydrogen bonds (Table 2, Figure 6). The length of the $\mathrm{O}-\mathrm{H}$ bond $(1.00 \AA)$ of the hydrogen oxalate anion is slightly longer than expected, which may correlate with its participation in a strong hydrogen bond. Similar $\mathrm{O}-\mathrm{H}$ bond lengths have been seen in related compounds [21]. Overall, this leads to a connectivity of the complex anions in the $a b$ plane with the $\mathrm{N}-\mathrm{H} \cdots \mathrm{O}$ bonds serving to link the anions in the $c$ direction.

\section{Experimental Section}

Compound 1 was prepared from $2.77 \mathrm{~g} \mathrm{BaC}_{2} \mathrm{O}_{4}, 3.6 \mathrm{~g} \mathrm{H}_{3} \mathrm{PO}_{3}$, and $1.3 \mathrm{~mL}$ diethylamine in $20 \mathrm{~mL}$ of water. The components were placed in a PTFE bottle, shaken well to form a milky slurry, and placed in an oven at $80{ }^{\circ} \mathrm{C}$ for two days. Product recovery by vacuum filtration yielded colorless blocks and bars of 1. IR $\left(\mathrm{KBr}, \mathrm{cm}^{-1}\right)$ : 2461w, $2157 \mathrm{w}, 2017 \mathrm{w}, 1589 \mathrm{vs}, 1309 \mathrm{~s}, 1221 \mathrm{~m}, 1156 \mathrm{~m}, 1068 \mathrm{~m}, 892 \mathrm{~m}$, $771 \mathrm{~m}, 662 \mathrm{w}$. The band at $2461 \mathrm{~cm}^{-1}$ is the characteristic phosphite $\mathrm{P}-\mathrm{H}$ stretch [22] and the various bands in the region 900-1200 $\mathrm{cm}^{-1}$ have been associated with $\mathrm{PO}_{3}$ modes [22]. The bands at 771, 1309 and $1589 \mathrm{~cm}^{-1}$ probably correspond to the $\delta(\mathrm{O}-\mathrm{C}-\mathrm{O}), v_{\mathrm{sym}}(\mathrm{COO})$ and $v_{\text {asym }}(\mathrm{COO})$ deformations respectively of the oxalate $-\mathrm{CO}_{2}$ groups [23]. The X-ray powder pattern for $\mathbf{1}$ could be matched to a simulation of the single-crystal structure, indicating phase purity.

Compound 2 was prepared by the same procedure, with ethylenediamine $(2.0 \mathrm{~mL})$ replacing diethylamine. Product recovery as above led to a mass of small colorless blocks and rods of 2. IR $\left(\mathrm{KBr}, \mathrm{cm}^{-1}\right): \sim 3200 \mathrm{~m}, 1583 \mathrm{~s}, 1303 \mathrm{~m}, 1217 \mathrm{~m}, 1150 \mathrm{~m}, 1063 \mathrm{~s}, 887 \mathrm{~m}, 772 \mathrm{w}$. The characteristic 772 , 1303 and $1583 \mathrm{~cm}^{-1}$ oxalate bands are assigned as above. Powder diffraction indicated that the product was almost phase pure with possibly a trace of barium oxalate.

The single-crystal data for $\mathbf{1}$ and $\mathbf{2}$ were collected on a Nonius KappaCCD diffractometer (graphite monochromated Mo K $\alpha$ radiation, $\lambda=0.71073 \AA$ ) at $120 \mathrm{~K}$. Data reduction with DENZO/HKL [24] then routinely proceeded in each case and empirical (multi-scan) absorption corrections were applied with SADABS [25], as summarized in the paragraphs below. For 1, the structure was solved by direct methods with SHELXS in space group $C 2 / c$ and the atomic model refined against $|F|^{2}$ with SHELXL [26]. For 2, attempts to solve the structure in space group $C 2 / m$ either by direct methods or Patterson maps were not successful and lower symmetry space groups were tried. The structure solved easily in space group $C m$ but a symmetry check with PLATON [27] indicated that $C 2 / m$ was the most appropriate symmetry and the atomic model was transformed to the latter space group. Full-matrix least-squares refinement then proceeded as for $\mathbf{1}$. The "observed data" threshold for calculating the $R(F)$ residuals was set as $I>2 \sigma(I)$. For 1 , the $\mathrm{H}$ atoms were located in difference maps and freely refined with the constraint $U_{\text {iso }}(\mathrm{H})=1.2 U_{\text {eq }}$ (carrier) applied. For 2, the $\mathrm{H}$ atoms of the organic cation 
were geometrically placed $(\mathrm{C}-\mathrm{H}=0.97, \mathrm{~N}-\mathrm{H}=0.89 \AA)$ and refined as riding atoms. The water and oxalate $\mathrm{H}$ atoms were located in difference maps and refined as riding atoms in their as-found relative positions. The constraint $U_{\text {iso }}(\mathrm{H})=1.2 U_{\text {eq }}$ (carrier) was applied in all cases. Full details are given in the deposited cifs.

Crystal data for 1: colorless block, $0.09 \times 0.06 \times 0.05 \mathrm{~mm}, \mathrm{C}_{2} \mathrm{H}_{4} \mathrm{Ba}_{2} \mathrm{O}_{10} \mathrm{P}_{2}, M_{\mathrm{r}}=531.38$, monoclinic, $C 2 / c$ (No. 15), $a=12.3829$ (3) $\AA, b=7.9124$ (2) $\AA, c=11.0858$ (3) $\AA, \beta=114.788$ (2), $V=986.10(4) \AA^{3}, Z=4, F(000)=952, T=120 \mathrm{~K}, \rho_{\text {calc }}=3.534 \mathrm{~g} \mathrm{~cm}^{-3}, \mu=8.304 \mathrm{~mm}^{-1}, T_{\min }=0.522$, $T_{\max }=0.682,5117$ reflections measured $(-16 \leq h \leq 15,-10 \leq k \leq 10,-14 \leq l \leq 14$; $\left.6.30^{\circ} \leq 2 \theta \leq 54.98^{\circ}\right), R_{\text {Int }}=0.034,1133$ merged reflections, 1115 with $I>2 \sigma(I), 79$ parameters, $R(F)=0.016, w R\left(F^{2}\right)=0.040, S$ (goodness-of-fit) $=1.143, w=1 /\left[\sigma^{2}\left(F_{\mathrm{o}}{ }^{2}\right)+3.6002 P\right]$, where $P=\left(F_{\mathrm{o}}{ }^{2}+2 F_{\mathrm{c}}{ }^{2}\right) / 3$, min. $/ \max . \Delta \rho=-0.53,+0.59$ e $\AA^{-3}$. Cambridge Database deposition number: CSD-826099.

Crystal data for 2: colorless block, $0.12 \times 0.08 \times 0.05 \mathrm{~mm}, \mathrm{C}_{10} \mathrm{H}_{18} \mathrm{BaN}_{2} \mathrm{O}_{18}, M_{\mathrm{r}}=591.6$, monoclinic, $C 2 / m$ (No. 12), $a=12.7393$ (7) $\AA, b=13.0111$ (7) $\AA, c=5.6050$ (3) $\AA, \beta=104.208$ (4), $V=900.62(8) \AA^{3}, Z=2, F(000)=584, T=120 \mathrm{~K}, \rho_{\text {calc }}=2.182 \mathrm{~g} \mathrm{~cm}^{-3}, \mu=2.310 \mathrm{~mm}^{-1}, T_{\min }=0.769$, $T_{\max }=0.893,5144$ reflections measured $\left(-15 \leq h \leq 16,-16 \leq k \leq 16,-7 \leq l \leq 7 ; 6.26^{\circ} \leq 2 \theta \leq 55.02^{\circ}\right)$, $R_{\mathrm{Int}}=0.048,1084$ merged reflections, 1056 with $I>2 \sigma(I), 77$ parameters, $R(F)=0.027$, $w R\left(F^{2}\right)=0.054, S$ (goodness-of-fit) $=1.091, w=1 /\left[\sigma^{2}\left(F_{\mathrm{o}}{ }^{2}\right)+0.0083 P^{2}+2.0292 P\right]$, where $P=\left(F_{\mathrm{o}}{ }^{2}+2 F_{\mathrm{c}}{ }^{2}\right) / 3$, min./max. $\Delta \rho=-0.69,+0.78$ e $\AA^{-3}$. Cambridge Database deposition number: CSD-826100.

\section{Conclusions}

We have prepared and structurally characterized the new phases $\mathrm{Ba}_{2}\left(\mathrm{C}_{2} \mathrm{O}_{4}\right)\left(\mathrm{H}_{2} \mathrm{PO}_{3}\right)_{2}$ and $\mathrm{C}_{2} \mathrm{H}_{10} \mathrm{~N}_{2} \cdot \mathrm{Ba}\left(\mathrm{H}_{2} \mathrm{O}\right)_{2}\left(\mathrm{HC}_{2} \mathrm{O}_{4}\right)_{4}$. So far as we can ascertain, they are the first examples of barium oxalates in combination with oxo-anions or organic cations. The deposition of the oxalate ion in $\mathbf{1}$ is notably twisted, whereas it is almost planar in $\mathbf{2}$. The barium ions show different, distinctive coordination polyhedra in these structures. The number of crystal structures containing nine- and ten-coordinate barium complexes in the Cambridge Structural Database (version 5.32 of November 2010 with two updates) [28] is almost the same, at 73 and 75 , respectively.

\section{Acknowledgements}

We thank the EPSRC national Crystallography Service (University of Southampton, England) for the X-ray data collections.

\section{References and Notes}

1. Mutin, J.-C.; Dusausoy, Y.; Protas, J. Structural description of endothermic decompositions in the form solid-1 $\rightarrow$ solid-2 + gas 1 . Crystal structure of barium oxalate, $2 \mathrm{BaC}_{2} \mathrm{O}_{4} \cdot \mathrm{H}_{2} \mathrm{O}$. J. Solid State Chem. 1981, 36, 356-364.

2. Mutin, J.-C.; Aubry, A.; Bertrand, G.; Joly, E.; Protas, J. Determination of crystal-structure of $\mathrm{BaC}_{2} \mathrm{O}_{4} \cdot \mathrm{H}_{2} \mathrm{O}$. C. R. Acad. Sci. (Paris), Ser. C. 1974, 278, 1001-1004. 
3. Mutin, J.-C.; Courtois, A.; Bertrand, G.; Protas, J.; Watelle-Marion, G. Determination of crystalstructure of $\mathrm{BaC}_{2} \mathrm{O}_{4} \cdot 2 \mathrm{H}_{2}$ O. C. R. Acad. Sci. (Paris), Ser. C. 1971, 273, 1512.

4. Neder, R.; Burghammer, M.; Schulz, H.; Christensen, A.N.; Krane, H.G.; Bell, A.M.T.; Hewat, A.W.; Altomare, A. Crystal structure determination of $\mathrm{BaC}_{2} \mathrm{O}_{4} \cdot 3.5 \mathrm{H}_{2} \mathrm{O} / \mathrm{D}_{2} \mathrm{O}$. Zeit. Kristallogr. 1997, 212, 305-309.

5. Borel, C.; Ghazzali, M.; Langer, V.; Ohrstrom, L. Network analysis of barium oxalates $\mathrm{Ba}\left(\mathrm{C}_{2} \mathrm{O}_{4}\right)_{m}\left(\mathrm{HC}_{2} \mathrm{O}_{4}\right)_{n}\left(\mathrm{H}_{2} \mathrm{C}_{2} \mathrm{O}_{4}\right)_{p}\left(\mathrm{H}_{2} \mathrm{O}\right)_{q}$, including the new, uniform, five-connected loh net. Inorg. Chem. Commun. 2009, 12, 105-108.

6. Mutin, J.-C.; Watelle, G.; Dusausoy, Y. Study of a lacunary solid phase I-thermodynamic and crystallographic characteristics of its formation. J. Solid State Chem. 1979, 27, 407-421.

7. Mutin, J.-C.; Watelle, G. Study of a lacunary solid phase II-morphological and kinetic characteristics of its formation. J. Solid State Chem. 1979, 28, 1-12.

8. Jung, W.-S.; Min, B.-K.; Park, J.; Yoon, D.-H. Formation mechanism of barium titanate by thermal decomposition of barium titanyl oxalate. Ceram. Int. 2011, 37, 669-672.

9. Kosanke, K.; Kosanke, B.J.; von Maltitz, I.; Sturman, B.; Shimizu, T.; Wilson, M.A.; Kubota, N.; Jennings-White, C.; Chapman, D. Pyrotechnic Chemistry; Journal of Pyrotechnics, Inc.: Whitewater, CO, USA, 2004; Chapter 14, p. 10.

10. Mandal, S.; Pati, S.K.; Green, M.A.; Natarajan, S. Inorganic-organic hybrid compounds: synthesis, structure, and magnetic properties of the first organically templated iron oxalatephosphite, $\left[\mathrm{C}_{4} \mathrm{~N}_{2} \mathrm{H}_{12}\left[\mathrm{Fe}_{4}{ }_{4} \mathrm{II}\left(\mathrm{HPO}_{3}\right)_{2}\left(\mathrm{C}_{2} \mathrm{O}_{4}\right)_{3}\right]\right.$, possessing infinite $\mathrm{Fe}-\mathrm{O}-\mathrm{Fe}$ chains. Chem. Mater. 2005, 17, 2912-2917.

11. Li, H.; Zhang, L.; Liu, L.; Jiang, T.; Yu, Y.; Li, G.; Huo, Q.; Liu, Y. Organic template-directed indium phosphite-oxalate hybrid material: synthesis and characterization of a novel 3D $\left[\mathrm{C}_{6} \mathrm{H}_{14} \mathrm{~N}_{2}\right]\left[\mathrm{In}_{2}\left(\mathrm{HPO}_{3}\right)_{3}\left(\mathrm{C}_{2} \mathrm{O}_{4}\right)\right]$ compound with intersecting channels. Inorg. Chem. Commun. 2009, 12, 1020-1023.

12. Zhu, Y.; Sun, Z.; Zhao, Y.; Zhang, J.; Lu, X.; Zhang, N.; Liu, L.; Tong, F. Synthesis, crystal structures and luminescence properties of lanthanide oxalatophosphonates with a threedimensional framework structure. New J. Chem. 2009, 33, 119-124.

13. Brown, I.D.; Altermatt, D. Bond-valence parameters obtained from a systematic analysis of the Inorganic Crystal Structure Database. Acta Cryst. 1985, B41, 244-247.

14. Ruiz-Martínez, A.; Casanova, D.; Alvarez, S. Polyhedral structures with an odd number of vertices: nine-atom clusters and supramolecular architectures. Dalton Trans. 2008, 2583-2591.

15. Corbridge, D.E.C. The crystal structure of magnesium phosphite hexahydrate, $\mathrm{MgHPO}_{3} \cdot 6 \mathrm{H}_{2} \mathrm{O}$. Acta Cryst. 1956, 9, 991-994.

16. Powell, D.R.; Smith, S.K.; Farrar, T.C.; Ross, F.K. Neutron and X-ray diffraction study of magnesium phosphite hexahydrate, $\left[\mathrm{Mg}\left(\mathrm{H}_{2} \mathrm{O}\right)_{6}\right]^{2+}\left[\mathrm{HPO}_{3}\right]^{2-}$. Acta Cryst. 1994, C50, 342-346.

17. Dewar, M.J.S.; Zheng, Y.-J. Structure of the oxalate ion. J. Mol. Struct. Theochem 1990, 209, $157-162$.

18. Robertson, J.H. Ammonium oxalate monohydrate: structure refinement at 30 K. Acta Cryst. 1965, $18,410-417$.

19. Robertson, J.H. Enantiomorphism of the oxalate ion in ammonium oxalate monohydrate. Acta Cryst. 1965, 18, 417-419. 
20. Green, E.A.; Daux, W.L.; Smith, G.M.; Wudl, F. Coordination complexes of groups 1 and 2. Potassium O,O'-catecholdiacetate. J. Am. Chem. Soc. 1975, 97, 6689-6692.

21. Fernandes, N.G.; Tellgren, R. Ammonium hydrogen oxalate hemihydrate: X-ray and neutron diffraction studies. Acta Cryst. 1989, C45, 499-504.

22. Scott, K.J.; Zhang, Y.; Clearfield, A. The synthesis and characterization of lanthanum phosphite phenylphosphonate mixed derivatives. Polyhedron 1994, 13, 1291-1300.

23. Trpkovska, M.; Šoptrajanov, B.; Pejov, L. Reinvestigation of the infrared spectra of calcium oxalate monohydrate and its partially deuterated analogues. Bull. Chem. Technol. Macedonia 2002, 21, 111-116.

24. Otwinowski, Z.; Minor, W. Processing of X-ray Diffraction Data Collected in Oscillation Mode. Methods in Enzymology; Carter, C.W., Jr., Sweet, R.M., Eds.; Academic Press: New York, NY, USA, 1997; Volume 276: Macromolecular Crystallography, part A, pp. 307-326.

25. Sheldrick, G.M. SADABS: Program for Empirical Absorption Correction of Area Detector Data; University of Göttingen: Göttingen, Germany, 1996.

26. Sheldrick, G.M. A short history of SHELX. Acta Cryst. 2008, A64, 112-122.

27. Spek, A.L. Structure validation in chemical crystallography. Acta Cryst. 2009, D65, 148-155.

28. Allen, F.H.; Motherwell, W.D.S. Applications of the Cambridge Structural Database in organic chemistry and crystal chemistry. Acta Cryst. 2002, B58, 407-422.

(C) 2011 by the authors; licensee MDPI, Basel, Switzerland. This article is an open access article distributed under the terms and conditions of the Creative Commons Attribution license (http://creativecommons.org/licenses/by/3.0/). 